\title{
A note on world precipitation during the last glaciation
}

\author{
By R. W. Galloway \\ With 1 figure
}

$\mathrm{S} \mathrm{u} \mathrm{m} \mathrm{mar} \mathrm{y} .72 \%$ of the present total world precipitation falls between the parallels of $40^{\circ} \mathrm{N}$ and $40^{\circ} \mathrm{S}$. On the assumption that during the last glaciation evaporation, and therefore precipitation, was $20 \%$ less than now, it is shown that a pluvial period in middle and low latitudes could not have occurred at that time.

$\mathrm{Zus}$ a m men fas sung. $72 \%$ der Gesamt-Niederschläge auf der Erde fallen zwischen den Breitengraden $40^{\circ} \mathrm{N}$ und $40^{\circ} \mathrm{S}$. Unter der Voraussetzung, daß während der letzten Eiszeit die Verdunstung - und damit die Niederschläge - $20 \%$ niedriger waren als heute, muß man annehmen, $\mathrm{da} ß \mathrm{zu}$ jener Zeit in den mittleren und niederen Breiten keine Pluvialzeit stattgefunden haben kann.

Many workers have maintained that during the last glaciation a major pluvial period occurred in latitudes lower than $40^{\circ}$ with increased rainfall encroaching si m u l t a n e o us ly on the desert belt from its equatorial and polar margins as a result of increased atmospheric circulation and consequent precipitation in the tropics and displacement towards the equator of the westerlies by the ice sheets (e.g. FLOHN, 1952; WILHELMY, 1957; Gentilli, 1961). The present note examines this hypothesis in the light of Flohn's (1953) estimate that world evaporation, and consequently precipitation, was at least $20 \%$ less during the last glaciation than today.

The present world annual precipitation amounts to $420 \times 10^{12} \mathrm{~m}^{3}$ (MöLlER, 1951) of which $72 \%$ falls between the parallels of $40^{\circ} \mathrm{N}$ and $40^{\circ} \mathrm{S}$ (Fig. 1). According to FLOHN's evaporation estimate total world precipitation during the last glaciation was no more than $336 \times 10^{12} \mathrm{~m}^{3}$. Polewards of latitude $40^{\circ}$ total precipitation must have been lower than the present figure of $120 \times 10^{12} \mathrm{~m}^{3}$ in view of the extensive evidence for steppe conditions in Europe and North America. Nevertheless it cannot have been negligeable since it was in these latitudes that the great ice sheets developed. It is a reasonable assumption that precipitation was $50 \%$ of the present and therefore amounted to $60 \times 10^{12} \mathrm{~m}^{3}$. Consequently precipitation equatorward of latitude $40^{\circ}$ cannot have exceeded $276 \times 1012 \mathrm{~m}^{3}$, only $92 \%$ of the present volume and clearly there was no overall increase in rainfall in middle and low latitudes.

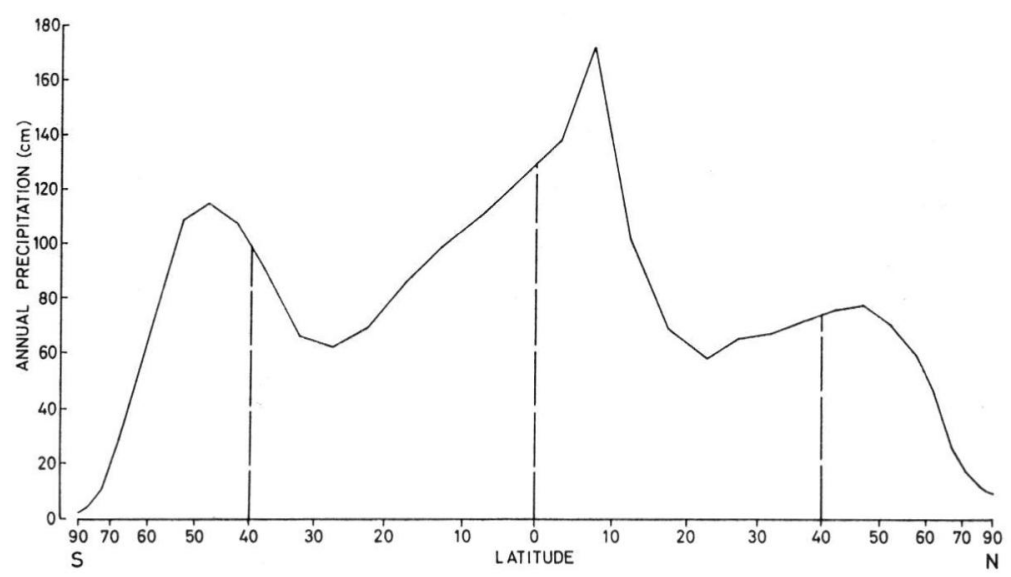

Fig. 1. Area graph of present world precipitation based on data from MöLLER 1951. 
Increased precipitation during the last glacial could only have occurred simultaneously on both equatorward and poleward margins of the desert belt if there were drastic modifications of the present circulation and associated rainfall patterns in the tropics and sub-tropics. However, circulation patterns deduced from the direction of snow accumulation in Pleistocene cirques and from the orientation of longitudinal dunes in Australia (of glacial age: FAIRBRIDGE, 1961) are similar to those of today. Furthermore, the glacial snowline as revealed by cirque floors, rises consistently towards what are now drier areas thus indicating that the general distribution of precipitation, if not the amounts, was the same then as now. It is therefore unlikely that low-latitude circulation during the last glaciation was significantly different from that of today.

An increase in precipitation in the desert belt during an ice age remains a possibility provided it were restricted to the poleward margin of the deserts and provided there were a corresponding diminution in the equatorial rain belt. However, even on the poleward margin of the desert belt much of the evidence cited in support of a "glacialpluvial" is suspect since there is strong evidence that the climate was much colder there during the last glaciation than previously believed (e.g. Hey, 1962; Ericson, Ewing, Wollin and Heezen, 1961; van Zinderen BaKKer, 1963). The drastic decrease in evaporation associated with these relatively cold conditions could account for many of the "pluvial" features. Furthermore, this evidence for cold conditions suggests that FLOHN's estimate of $20 \%$ decrease in evaporation during the last glaciation, a figure which he himself regarded as a minimum, is conservative. A figure of $30 \%$ is by no means improbable and implies that the last glaciation must have been a time of markedly lower precipitation even in middle and low latitudes. According to the premises outlined here one would expect true pluvials in present day desert areas to have coincided with interglacial or post-glacial thermal optima when world evaporation, and consequently precipitation, was at a maximum.

References

Ericson, D. B., Ewing, M., Wollin, G., and Heezen, B. C.: Atlantic deep sea sediment cores. Bull. Geol. Soc. Amer. 72, 193-286. 1961.

Fairbridge, R. W.: Eustatic changes in sea level. - Physics and Chemistry of the Earth 4, 99-185. 1961.

Flohn, H.: Allgemeine atmosphärische Zirkulation und Paläoklimatologie. - Geolog. Rundsch. 40, 153-178. 1952. - - Studien über die atmosphärische Zirkulation in der letzten Eiszeit. Erdkunde 7, 266-275. 1953.

Gentilli, J.: Quaternary climates of the Australian Region. - Ann. New York Acad. Sci. 95, 465-501. 1961.

Hex, R. W.: The Quaternary and Palaeolithic of Northern Libya. - Quaternaria 6, 435-449. 1962.

MöLler, F.: Vierteljahreskarten des Niederschlags für die ganze Erde. - Pet. Mitt. 95, 1-7, 195,1.

VAN ZiNDEREN BAKKER, E. M.: Symposium on early man and his environment in Southern Africa. Palaeobotanical studies. - South African Journ. Sci. 59, 332-340. 1963.

Wilhelmy, H.: Eiszeit und Eiszeitklima in den feuchttropischen Anden. - Pet. Mitt. Ergänzungsheft 262, 281-310. 1957.

Manuskr. eingeg. 20. 4. 1965.

Anschrift des Verf.: Dr. R. W. Galloway, Division of Land Research and Regional Survey, CSIRO, Canberra, Australia. 